\title{
STABILITAS EMOSI PELAKU PERNIKAHAN DINI DALAM MENDIDIK ANAK BALITA
}

\author{
Lu' Luul Jannatunnaim \\ e-mail: luluajannatunnaim@gmail.com \\ Alumni Bimbingan Konseling Fakultas Dakwah \\ dan Ilmu Komunikasi UIN Mataram
}

\begin{abstract}
The rate of early marriage from year to year continues to increase due to economic factors, family internal factors, and social factors. Most early marriages are still middle school / high school students who do not have good emotional stability and tend to do everything they want without thinking about the impact that will occur. Many of the early marriages have children, where in educating children they unconsciously apply permissive education patterns. The personal circumstances and attitudes of each child are different, making the task of educating hard to implement, and influencing the emotional state of parents. The results showed that the emotional stability of early marriages in educating children is not good, this is because early marriages are still easily influenced by negative emotions that can be seen from the emotional response shown. Excessive emotional response is not in accordance with the notion of emotional stability, namely a permanent emotional state, not easily changed, and the response shown is not excessive. In relieving negative emotions and resolving problems that occur, early marriages more often submit to the situation assuming that emotions will be lost if left unchecked, without any effort to find a way out or a method of solving the problem accordingly. Although early marriages do not have good emotional stability, some early marriages have been able to maintain their emotional stability by calming themselves down and solving problems that are sources of emotion.
\end{abstract}

Keywords: Emotional Stability, Actors of Early Marriage, Educating Children 


\begin{abstract}
Abstrak
Angka pernikahan dini dari tahun ke tahun terus mengalami peningkatan yang disebabkan oleh faktor ekonomi, faktor internal keluarga, dan faktor pergaulan. Kebanyakan pelaku pernikahan dini masih SMP/SMA yang belum memiliki stabilitas emosi yang baik dan cenderung melakukan segala yang diinginkan tanpa memikirkan dampak yang akan terjadi. Banyak dari pelaku pernikahan dini telah memiliki anak, dimana dalam mendidik anak secara tidak sadar menerapkan pola pendidikan permisif. Keadaan pribadi dan sikap setiap anak yang berbeda, menjadikan tugas mendidik menjadi berat untuk dilaksanakan, dan berpengaruh pada keadaan emosi orang tua. Hasil penelitian menunjukkan bahwa kestabilan emosi pelaku pernikahan dini dalam mendidik anak belum baik, hal ini dikarenakan pelaku pernikahan dini masih mudah terpengaruh emosi negatif yang dapat dilihat dari respon emosi yang ditunjukkan. Respon emosi berlebihan tidak sesuai dengan pengertian stabilitas emosi, yaitu keadaan emosi yang tetap, tidak mudah berubah, dan respon yang ditunjukkan tidak berlebihan. Dalam meredakan emosi negatif dan menyelesaikan permasalah yang terjadi, pelaku pernikahan dini lebih sering menyerahkan pada keadaan dengan anggapan bahwa emosi tersebut akan hilang jika dibiarkan, tanpa ada usaha untuk mencari jalan keluar atau metode penyelesaian masalah yang sesuai. Meski pelaku pernikahan dini belum memiliki stabilitas emosi yang baik, namun beberapa pelaku pernikahan dini telah mampu untuk menjaga stabilitas emosi mereka dengan cara menenangkan diri terlebih dahulu dan menyelesaikan permasalahan yang menjadi sumber emosi.
\end{abstract}

Kata Kunci: Stabilitas Emosi, Pelaku Pernikahan Dini, Mendidik Anak 


\section{A. Pendahuluan}

Menikah merupakan salah satu tahapan penting dalam kehidupan seseorang. Untukitu, pernikahan harus dipersiapkan dengan matang, baik itu dari segi mental, fisik, ekonomi, dan lain sebagainya. Namun bagaimana jadinya jika suatu pernikahan dilakukan dengan tanpa adanya persiapan yang matang, terlebih lagi usia dari pasangan bisa dikatakan masih dibawah umur. Pernikahan yang masih dibawah umur ini lebih sering disebut dengan pernikahan dini. Hukum Indonesia yang tercantum dalam UU No.1 thn 1974 tentang Perkawinan tidak memperbolehkan terjadinya pernikahan dini, karena pada dasarnya pasangan yang menikah muda masih bisa dikatakan sebagai anak-anak atau remaja ${ }^{1}$ yang masih memiliki ego dan stabilitas emosi yang belum sempurna. Namun dalam hukum Islam, pernikahan dini adalah pernikahan yang dilakukan pasangan yang belum baligh (sudah dibebani dengan hukum syara'). ${ }^{2}$ Pasangan

1 Departemen Agama RI, Bahan Penyuluhan Hukum: Undang-Undang No.7 Tahun 1989 tentang Peradilan Agama, UU No.1/Th 1974 tentang Perkawinan dan Inpres No.1/1991 tentang. Kompilasi Hukum Islam, (Jakarta: DEPAG RI, 1996/1997), 63.

2 H. Andi Syamsu Alam, Usia Ideal Memasuki Dunia Perkawinan: Sebuah Ikhtiar pernikahan dini yang masih dikatakan sebagai remaja, masih belum stabil secara emosional disangsikan bisa mendidik anak-anaknya kelak. Karena dalam mendidik anak, orang tua harus menjadi contoh yang baik bagi anak-anaknya. Sebab keluarga sebagai sekolah pertama bagi anak-anak sebelum memasuki sekolah formal (TK, SD, SMP, SMA, dan universitas), khususnya orang tua harus mampu memberikan contoh yang baik dengan salah satu cara memanajemen emosi atau menyeimbangkan antara emosi positif dan emosi negatif.

Orang tua yang mampu menyeimbangkan antara emosi positif dan emosi negatif adalah orang tua hebat yang dapat menjadikan anakanaknya memiliki kepribadian yang baik. Namun ketika orang tua kurang mampu memajemen emosi dan menunjukkan emosi yang dirasakan (terlebih emosi negatif) kepada anaknya, maka anak tersebut akan memiliki kepribadian yang tidak jauh berbeda dengan orang tuanya.

Terlepas dari banyaknya kasus pernikahan dini yang terjadi di Kelurahan Panji Sari, menjadikan banyak pasangan muda (hasil pernikahan dini) kerap kali dilanda permasalahan yang berasal dari

Meroujudkan Keluarga Sakinah, (Jakarta: Kencana Mas Publising House, 2005), 42. 
hal sepele berakhir pada kekerasan terhadap istri dan anak. Permasalahan rumah tangga yang kerap kali dihadapi pasangan suami istri adalah permasalahan yang sudah pernah dihadapi oleh pasangan-pasangan terdahulu, seperti permasalahan ekonomi, permasalahan dengan mertua atau ipar, permasalahan latar belakang pendidikan yang dijadikan acuan pintar tidaknya pasangan dalam mengasuh anak, permasalahan dengan lingkungan tempat tinggal, dan permasalahan dalam mendidik anak yang membutuhkan kesabaran dan kerjasama antara suami dan istri.

Permasalahan yang dihadapi pasangan suami istri membutuhkan kesabaran, ketenangan pikiran, dan kemampuan dalam mengelola emosi (menyeimbangkan emosi positif dan emosi negatif) dalam menyelesaikan segala permasalahan yang dihadapi. Namun, kenyataannya banyak pasangan suami istri yang belum bisa mengelola emosi dengan baik yang berdampak pada anak-anak mereka, baik dari segi fisik dan psikis. Mengasuh dan mendidik anak merupakan pr terbesar bagi setiap pasangan, baik itu pasangan pelaku pernikahan dini maupun pasangan yang sudah siap secara fisik dan mental dilihat dari segi umur dan UU Perkawinan. Di Kelurahan Panji Sari sendiri, baik itu pasangan hasil pernikahan dini maupun pasangan dewasa kebanyakan menerapkan pola pengasuhan permisif (cenderung memberikan kebebasan kepada anak dengan menerima dan memaklumi segala perilaku dan tindakan anak, namun kurang menuntut sikap tanggung jawab dan keteraturan perilaku anak, serta orang tua memposisikan diri sebagai sumber daya bagi terpenuhinya keinginan anak), pola pengasuhan otoriter (cenderung mengatur dan menekan segala kegiatan dan tingkah laku anak agar sesuai dengan aturan standar dan keinginan orang tua), dan pola pengasuhan otoritatif/ demokrasi (memberikan penjelasan secara rasional maksud dari peraturan yang diberlakukan dan mendorong anak untuk mematuhi aturan dengan kesadaran sendiri, serta memberikan kebebasan dengan tetap meminta pertanggung jawaban anak atas segala yang diperbuat serta memberikan respon terhadap segala sesuatu yang berhubungan dengan anak). ${ }^{3}$

Kebanyakan pasangan pelaku pernikahan dini, di Kelurahan Panji Sari menerapkan pola pengasuhan permisif, dimana membiarkan anak melakukan segala sesuatu yang diinginkan tanpa adanya pemberian

3 Sri Lestari, Psikologi Keluarga: Penanaman Nilai dan Penangan Konflik dalam Keluarga, (Jakarta: Kencana, 2013), 48-49. 
hukuman yang bersifat jera bagi anakanak yang melakukan kesalahan yang tidak sesuai dengan hukum dan norma yang berlaku.

Atas dasar itulah, peneliti tertarik untuk meneliti fenomena sosial yang terjadi di Kelurahan Panji Sari disebabkan oleh banyaknya kasus pasangan pelaku pernikahan dini yang belum mampu menstabilkan emosinya dalam mendidik anak-anak dan seringkali tersulut emosi negatif ketika menghadapi masalah yang berimbas pada pembentukan karakter anak yang dinilai negatif oleh norma masyarakat, seperti melawan dan kurang sadar akan hukum dan norma yang berlaku.

Dengan demikian, sangat penting bagicalon pasanganyangakan menikah siap secara mental dan fisik karena menikah bukan perkara yang hanya selesai dengan kata "sah", melainkan pernikahan adalah gerbang kehidupan baru, dimana suami atau istri dituntut untuk bisa melalui segala rintangan yang akan dihadapinya pada lembar pernikahan. Dari segala rintangan yang dihadapi itulah, pasangan suami istri harus bisa bekerjasama dalam menyelesaikan permasalahan yang ada dan harus mampu menstabilkan emosi mereka dalam keadaan apapun. Karena dengan emosi yang stabil dan pikiran yang jernih, pasangan suami istri akan lebih mudah untuk mencari jalan keluar bersama. Sehingga, tidak akan ada celah untuk masalah baru (hal yang tidak diinginkan) bisa masuk ke dalam kehidupan keluarga tersebut.

\section{B.StabilitasEmosiPelakuPernikahan Dini Dalam Mendidik Anak Balita}

Stabilitas emosi diartikan sebagai kondisi emosi yang tetap, tidak mudah berubah, tidak labil, tidak mudah mengalami gangguan emosional, memiliki kontrol emosi yang baik dan mampu mengendalikan emosi secara tepat ketika menghadapi kondisi yang menyenangkan ataupun ketika menghadapi masalah dalam hidup, sehingga respon yang ditampilkan tidak berlebihan.Stabilitas emosi yang dimiliki setiap orang akan berbeda dikarenakan adanya perbedaan kondisi emosi pada saat menghadapi masalah yang sama. Bisa saja respon emosi yang ditunjukkan pelaku pernikahan dini lebih baik dari respon emosi yang ditunjukkan orang tua dewasa dalam menghadapi kenakalan anaknya dan sebaliknya. Hal ini dikarenakan stabilitas emosi sama halnya dengan kedewasaan yang tidak dapat diukur olehbanyaknyaumurseseorang. Karena stabil tidaknya emosi seseorang dapat dilihat dari seberapa baik respon emosi yang ditunjukkannya ketika dalam 
keadaan emosi negatif, dimana respon emosi yang ditunjukkan dipengaruhi oleh pengalaman, keadaan dan waktu saat individu merasakan emosi yang sama dengan penyebab yang berbeda.

Stabilitas emosi tidak hanya dibutuhkan pada keadaan-keadaan tertentu yang memicu terjadinya emosi negatif, akan tetapi stabilitas emosi juga dibutuhkan pada saat mendidik anak. Karena mendidik anak bukanlah perkara yang mudah, tetapi merupakan tugas dan tanggung jawab besar yang membutuhkan kesabaran dan kerjasama antar pasangan.Dalam mendidik anak, setiap anak memiliki karakter dan sikap yang berbeda antara anak yang satu dengan anak lainnya, menjadikan tugas mendidik dirasa sangat berat dan sering menjadi sumber stress bagi orang tua, terlebih bagi pelaku pernikahan dini dimana mereka dikatakan sebagai bukan lagi anak-anak dan bukan pula orang dewasa.Keadaan pelaku pernikahan dini yang dianggap belum mampu mendidik anak dengan keadaan emosi yang sering berubahubah, maka untuk melihat keadaan emosi pelaku pernikahan dini telah stabil atau tidak dapat dilihat melalui tiga aspek penyusun stabilitas emosi, antara lain:

\section{Kontrol Emosi}

Semiun menjelaskanbahwakontrol emosi tidak berarti emosi ditekan atau tidak boleh diungkapkan, akan tetapi melatih emosi dan mengendalikan emosi tersebut sehingga tidak merugikan diri sendiri dan orang lain. ${ }^{4}$ Dimana kondisi emosi yang stabil akan ditunjukkan dengan adanya kendali atau kontrol emosi pada saat yang ekstrim sekalipun. ${ }^{5}$ Dengan kata lain, kontrol emosi merupakan kemampuan seseorang menunjukkan emosi secara wajar sesuai dengan stimulus yang diterima agar emosi yang ditunjukkan tidak merugikan diri sendiri dan orang lain.

Pelaku pernikahan dini yang ada di Kelurahan Panji Sari, ada yang belum memiliki kontrol emosi yang baik dan ada yang berada dalam proses menuju kontrol emosi yang baik. Hal ini dilihat dari bagaimana pelaku pernikahan dini memberikan respon emosi terhadap stimulus atau keadaan-keadaan yang memicu terjadinya emosi.

Seseorangdapatdikatakanmemiliki kontrol emosi yang baik, jika individu tersebut memiliki sikap mampu menahan amarah di depan umum dan intensitas ledakan emosi yang rendah. Dari beberapa narasumber yang telah diwawancarai, seperti yang telah

4 Yustinus Semiun, Kesehatan Mental 1: Pandangan Umum Mengenai Penyesuaian Diri dan Kesehatan Mental serta Teori-Teori Terkait, (Yogyakarta: Kanisius, 2006), 9.

5 Sheema Alem, "Emotional Stability among College Youth", (Vol. 32, Nomor 1-2, Januari - Juli 2005), 100-102. 
dijelaskan pada bab paparan data dan temuan, beberapadarimerekamengaku sangat mudah marah dengan hal kecil yang sebenarnya tidak wajar menjadi pemicu terjadinya emosi negatif dan cenderung memberikan respon emosi berlebihan yang tidak sesuai dengan stimulus emosi yang diterima. Ketika berada dalam keadaan emosi negatif tersebut, menunjukkan emosi yang dirasakan menurut pelaku pernikahan dini adalah hal wajar, karena dengan menunjukkan emosi yang dirasakan mampu memberikan kelegaan tersendiri. Namun, pengungkapan emosi berlebihan yang mereka lakukan berakibat buruk bagi diri sendiri dan orang lain dan lingkungan sekitar. Berbeda halnya dengan narasumber yang menunjukkan respon emosi tidak berlebihan ketika menerima stimulus emosi, dilihat dari cara mereka menghadapi permasalahan yang ada dengan cara memilih untuk menghindar sementara waktu untuk menjernihkan pikiran serta berusaha untuk menyelesaikan masalah yang menjadi penyebab emosi.

Dengan demikian setiap individu, baik pelaku pernikahan dini maupun bukan, harus senantiasa belajar mengontrol emosi atau menyesuaikan emosi yang akan ditunjukkan sesuai dengan stimulus emosi yang diterima, baikitu emosi positif atau emosinegatif.
Karena kemampuan mengontrol emosi akan berpengaruh kepada perasaan nyaman dan tenang dalam diri serta memberikan pengaruh positif pada semua aspek, terlebih dalam aspek mendidik anak, dimana orang tua yang mampu mengontrol emosi akan lebih tenang dan sabar dalam menghadapi segala tingkah laku anak yang sering membuat stress.

\section{Respon Emosi}

Stabilitas emosi dapat dicapai apabila individu dapat menemukan suatu cara untuk menghadapi situasi bahaya sehingga emosi yang tidak menyenangkan dapat turun atau menjadi reda. Respon emosi yang ditunjukkan seseorang dapat menggambarkan stabilitas emosinya. Safaria dan Saputra menjelaskan bahwa individu berusaha menyeimbangkan respon emosi positif dan respon emosi negatif, dimana bentuk respon yang dipilihdanditampilkansaatmenghadapi situasi tertentu dapat menunjukkan stabilitas emosi seseorang. ${ }^{6}$

Kemampuan untuk memberikan respon emosi positif terhadap segala bentuk stimulus emosi yang diberikan, baik stimulus emosi negatif atau positif mencerminkan bahwa individu

6 Triantoro Safaria \& Nofrans Eka Saputra, Manajemen Emosi: Suatu Panduan Cerdas Bagaimana Mengelola Emosi Positif Dalam Hidup Anda, (Jakarta: PT Bumi Aksara, 2012), 12-14. 
telah mampu untuk menstabilkan emosinya. Sesuai dengan yang dijabarkan peneliti pada bab paparan data dan temuan, menjelaskan bahwa pelaku pernikahan dini ada yang mampu memberikan respon emosi yang positif, dimana stabilitas emosi ditandai oleh kemampuan memberikan respon positif dari pada respon negatif walaupun berada dalam keadaan emosi negatif. Seseorang yang mampu memberikan respon positif, mampu berpikir dampak yang akan ditimbulkan jika memberikan respon negatif, baik itu dampak bagi diri sendiri dan orang lain. Namun, ada juga beberapa pelaku pernikahan dini yang memberikan respon emosi negatif ketika menghadapi masalah. Respon negatif yang ditampilkan merupakan akibat dari ketidaknyamanan yang dirasakan dengan lingkungan tempat tinggal. Keadaan diri yang merasa ditekanolehlingkungan tempat tinggal, khususnya lingkungan keluarga baru (tinggal bersama mertua) menjadikan mereka lebih banyak memberikan respon negatif dari pada respon postitif saat menghadapi masalah, dimana akan berakibat buruk pada diri sendiri dan orang lain.

Oleh sebab itu, semua individu baik orang tua dewasa maupun pelaku pernikahan dini harus belajar untuk memberikan respon positif terhadap segala stimulus emosi (terlebih stimulus negatif) dengan cara lebih sabar dan tidak gampang tersulut emosi negatif yang nantinya berdampak pada kekerasan, perusakan yang dapat merugikan diri sendiri dan orang lain agar tercapai stabilitas emosi yang diharapkan.

\section{Kematangan Emosi}

\begin{tabular}{lcr}
\multicolumn{1}{c}{ Kematangan } & emosi & adalah \\
kemampuan & seseorang & untuk \\
mengendalikan & emosinya & dalam
\end{tabular} menghadapi berbagai situasi dan melakukan reaksi emosi sesuai dengan tingkat perkembangannya yang dapat dilihat dari kemampuan individu untuk menyesuaikan diri terhadap stress, tidak mudah khawatir, tidak mudah cemas, dan tidak mudah marah, mampu menerima kenyataan, mampu beradaptasi dengan mudah, mampu merespon dengan tepat dan mampu berempati. ${ }^{7}$

Anggapan masyarakat bahwa ketika seseorang telah menikah dianggap telah dewasa dalam segi pemikiran walaupun dalam segi fisik masih muda, hal ini didasari oleh pemikiran bahwa setiap orang yang menikah akan memiliki anak dan tanggung jawab yang besar, oleh sebab itu mau tidak mau setiap orang yang telah menikah haruslah dewasa.

7 Alex Sobur, Psikologi Umum, Cet. ke-6, (Bandung: CV Pustaka Setia, 2016), 346. 
Terlepas dari pemikiran tersebut, kematangan emosi yang merupakan salah satu aspek dari stabilita emosi tergantung dari pengalaman emosi individu untuk menyesuaikan diri terhadap stress, tidak mudah khawatir, tidak mudah cemas, dan tidak mudah marah. Dengan keadaan pelaku pernikahan dini yang jika dilihat dari segi umur dan fisik, belum memiliki pengalaman emosi yang cukup untuk mampu menyesuaikan diri terhadap emosi negatif karena mereka tetaplah dilihat sebagai remaja. Namun kenyataannya, pelaku pernikahan dini dituntut untuk mampu menyesuaikan diri terhadap emosi negatif guna mencapai kematangan emosi.

Kematangan emosi juga digambarkan sebagai seberapa jauh penerimaan diri seseorang terhadap keadaan diri mereka saat ini, dengan kata lain tidak adanya penyesalan yang dirasakan, karena dengan telah bisa menerima keadaan diri saat ini mampu memberikan kepuasaan atau rasa bersyukur bagi seseorang. Akan tetapi, beberapa pelaku pernikahan dini di Kelurahan Panji Sari belum bisa menerima keadaan dirinya yang telah menikah. Halinidisebabkan oleh rasairi atau rasa minder karena memutuskan untuk menikah dini, dimana pada saat yang bersamaan, teman-teman yang seumuran masih bisa bebas untuk melakukan segala hal menyenangkan tanpa adanya kekangan dari suami atau istri. Rasa ketidakpenerimaan pada keadaan diri sendiri, pada akhirnya akan membuat seseorang terus merasa kekurangan dan mencela diri sendiri yang berdampak pada ketidakstabilannya emosi. Berbeda halnya dengan pelaku pernikahan dini yang sudah mulai bisa menerima keadaan dirinya, dan berusaha untuk terus memperbaiki keadaan menjadi lebih baik demi kepentingan keluarga, menggambarkan bahwa ia sedang dalam proses menuju kematangan emosi.

Mampu menyesuaikan diri terhadap stress, tidak mudah marah, tidak mudah khawatir dan cemas, tidak mudah marah, dan mampu menerima keadaan diri merupakan ciri-ciri dari kepribadianyangmemilikikematangan emosi yang baik. Kematangan emosi tidak hanya wajib dimiliki oleh orang tua saja, akan tetapi semua individu diwajibkan untuk memiliki kematangan emosi yang mampu menjadikan seseorang itu memiliki stabilitas emosi yang baik.

\section{Cara Pelaku Pernikahan Dini Menjaga Stabilitas Emosi}

Stabilitas emosi yang diartikan sebagai keadaan emosi yang tetap dan mampu mengendalikan emosi secara 
tepat sesuai dengan keadaan atau situasi yang dihadapi, menjadikan setiap individu mempunyai cara yang berbeda untuk menjaga stabilitas emosi mereka. Cara individu dalam mengatasi dan menyelesaikan masalah yang dihadapi, secara tidak langsung mencerminkan bagaimana individu tersebut menjaga emosinya agar tetap stabil. Seperti yang diungkapkan oleh Safaria dan Saputra, menjelaskan bahwa sebagian besar manusia dalam mengatasi dan menyelesaikan masalah yang dihadapi, sepenuhnya menggunakan pendekatan spiritual, yaitu dengan beribadah, berdzikir kepada kekuatan Tuhan, dan berpendapat bahwa Tuhan akan menolongnya dengan limpahan rahmat-Nya, terlepas dari agama dan kepercayaan yang dianut oleh masingmasing individu. ${ }^{8}$ Dimana individu akan melakukan usaha penyelesaian masalah sekaligus menemukan cara untuk menjaga stabilitas emosi sesuai dengan pengalaman, keadaan, dan waktu saat individu itu mengelola emosinya. ${ }^{9}$

Keputusan pemilihan stategi coping (usaha untuk menyelesaikan masalah) dan respon yang dipakai untuk menghadapi situasi yang penuh

8 Triantoro Safaria dan Nofrans Eka Saputra, Manajemen Emosi: Sebuah Panduan Cerdas Bagaimana Mengelola Emosi Positif Dalam Hidup Anda, (Jakarta: PT Bumi Aksara, 2012), 98.

$9 \quad$ Ibid., 99. tekanan tergantung dari dua faktor, yaitu faktor eksternal yang termasuk ingatan pengalaman dari berbagai situasi dan dorongan sosial, serta seluruh tekanan dari situasi penting dalam kehidupan; faktor internal yang termasuk gaya coping yang biasa dipakai dalam kehidupan sehari-hari sesuai dengan kepribadiannya. ${ }^{10}$

Kebiasaan setiap orang berbeda dalamusahanyamenyelesaikanmasalah yang sekaligus sebagai cara untuk menjaga emosi agar tetap stabil. Dari kebiasaan inilah, individu akan belajar bagaimana cara untuk menyelesaikan masalah dan bagaimana cara untuk menjaga emosi agar tidak meledakledak (stabil), agar bisa memperoleh keadaan nyaman bagi diri individu itu sendiri sesuai dengan pengalaman emosi yang dirasakannya.

Kebiasaan penyelesaian masalah yang berbeda pada setiap individu bukan berarti tidak memiliki persamaan dalam respon emosi yang ditunjukkan ketika menghadapi permasalahan, dimana hampir setiap individu memiliki cara untuk menjaga emosi yang sama, yaitu dengan menenangkan diri dari emosi negatif yang menguasai diri dengan cara menarik napas panjang dan berwudhu sesuai dengan anjuran agama Islam,

10 Ibid, 103. 
mengingat dampak yang akan terjadi dari emosi negatif yang berlebihan, membaca istigfar, memaafkan dan melupakan, belajar sabar dengan cara lebih banyak menjadi pendengar dari pada berbicara, intropeksi diri, melakukan hal yang menyenangkan untuk rileksasi, menyelesaikan masalah yang menjadi penyebab emosi, dan tidak mengambil keputusan saat sedang dalam emosi negatif. ${ }^{11}$

Kebiasaan peradaan emosi negatif dengan cara menyerahkan sepenuhnya pada keadaan, dengan anggapan bahwa emosi negatif tersebut akan hilang dengan sendirinya jika dibiarkan tanpa ada usaha untuk mencari jalan keluar atau metode penyelesaian masalah yang sesuai merupakan kebiasaan peredaan emosi yang dilakukan oleh pelaku pernikahan dini di Kelurahan Panji Sari, dimana pelaku pernikahan dini menitipkan anak-anak mereka untuk diasuh sementara oleh keluarga terdekat sampai emosi negatif yang dialami tidak lagi mempengaruhinya. Beberapa pelaku pernikahan dini juga melakukan penenangan terhadap diri mereka sebelum menyelesaikan masalah yang menjadi penyebab emosi, karena mereka berpendapat bahwa usaha menyelesaikan masalah dalam keadaan marah tidak akan

11 Yadi Purwanto dan Rahmat Mulyono, Psikologi Marah: Perspektif Psikologi Islam, (Bandung: PT Refika Aditama, 2006), 15. menyelesaikan masalah, akan tetapi akan memperburuk keadaan, merupakan cara meraka untuk menjaga emosi tetap stabil. Namun ada juga yang berpendapat bahwa mengekspresikan emosiyangdirasakan mampu memberikan rasa lega, tetapi tidak secara menyeluruh karena tidak semua orang dapat menerima luapan ekspresi emosi negatif seseorang. Peluapan ekspresi emosi negatif yang berlebihan akan memberikan dampak tidak menyenangkan, baik untuk diri sendiri maupun orang lain.

\section{Penutup}

Pelaku pernikahan dini belum memiliki stabilitas emosi yang baik jika diukur dari tiga aspek penyusun stabilitas emosi. Pertama, kontrol emosi adalah keadaan seseorang mampu menunjukkan emosi secara wajar dan tidak merugikan diri sendiri dan orang lain, mampu menahan amarah di depan umum, dan intensitas ledakan emosi yang rendah; Respon emosi adalah keadaan seseorang mampu menunjukkan lebih banyak emosi positif dari pada emosi negatif walaupun berada dalam keadaan emosi negatif, mampu berpikir dampak yang akan ditimbulkan jika memberikan respon negatif baik untuk diri sendiri dan orang lain; Kematangan emosi adalah keadaan seseorang mampu 
menyesuaikan diri terhadap stress, tidak mudah khawatir, tidak mudah cemas, dan tidak mudah marah, mampu menerima kenyataan, mampu beradaptasi dengan mudah, mampu merespon dengan tepat dan mampu berempati. Kedua, pelaku pernikahan dini belum mampu menjaga stabilitas emosi dalam mendidik anak balita dengan baik karena kebiasaan membiarkan permasalahan hilang dengan sendiri tanpa ada cara atau Bedftsin Rutstalmenyelesaikannya.

Alam, Syamsu, H. Andi, Usia Ideal Memasuki Dunia Perkawinan: Sebuah Ikhtiar Mewujudkan Keluarga Sakinah, (Jakarta: Kencana Mas Publising House, 2005)

Alem, Sheema, "Emotional Stability among College Youth", (Vol. 32, Nomor 1-2, Januari - Juli 2005)

Departemen Agama RI, Bahan Penyuluhan Hukum: UndangUndang No.7 Tahun 1989 tentang Peradilan Agama, UU No.1/Th 1974 tentang Perkawinan dan Inpres No.1/1991 tentang Kompilasi Hukum Islam, (Jakarta: DEPAG RI, 1996/1997)

Lestari, Sri, Psikologi Keluarga: Penanaman Nilai dan Penangan
Konflik dalam Keluarga, (Jakarta: Kencana, 2013)

Purwanto, Yadi dan Mulyono, Rahmat, Psikologi Marah:Perspektif Psikologi Islam, (Bandung: PT Refika Aditama, 2006)

Safaria, Triantoro \& Saputra, Eka, Nofrans, Manajemen Emosi: Suatu Panduan Cerdas Bagaimana Mengelola Emosi Positif Dalam Hidup Anda, (Jakarta: PT Bumi Aksara, 2012)

Safaria, Triantoro dan Saputra, Eka, Nofrans, Manajemen Emosi: Sebuah Panduan Cerdas Bagaimana Mengelola Emosi Positif Dalam Hidup Anda, (Jakarta: PT Bumi Aksara, 2012)

Semiun, Yustinus, Kesehatan Mental 1: Pandangan Umum Mengenai Penyesuaian Diri dan Kesehatan Mental serta Teori-Teori Terkait, (Yogyakarta: Kanisius, 2006)

Sobur, Alex, Psikologi Umum, Cet. Ke-6, (Bandung: CV Pustaka Setia, 2016) 